Note

\title{
Desensitization to Somatostatin Analogue (Octreotide) Observed in a Patient with Acromegaly
}

\author{
KazUTAKa HARAGUCHI, MasayuKi OHTAKA, Kazunaga TAKAZAWA, \\ TOYOSHI ENDO, AND TOSHIMASA ONAYA
}

The Third Department of Internal Medicine, University of Yamanashi Medical School, Tamaho, Yamanashi 409-38, Japan

\begin{abstract}
We encountered a 33-year-old female patient with a pituitary growth hormone (GH)-secreting macroadenoma. The patient was treated with somatostatin analogue (Octreotide) in combination with bromocriptine for 2 months before a transsphenoidal adenomectomy was carried out. Octreotide (300$800 \mu \mathrm{g} /$ day) in combination with bromocriptine was effective in reducing the size of the adenoma by $36 \%$, but produced only a marginal decrease in serum GH. After the operation, bromocriptine alone (15 $\mathrm{mg} /$ day) did not lower the level of $\mathrm{GH}$ which was produced by residual adenoma tissue. When octreotide (200 $\mu \mathrm{g} /$ day) was resumed along with the bromocriptine one year after the operation, it effectively lowered serum GH for 6 months. Thereafter, octreotide therapy became ineffective with a concomitant rise in serum GH and somatomedin C, which was not accompanied by an increase in tumor size. This was a rare case of acromegaly that showed desensitization to octreotide after long-term treatment.
\end{abstract}

Key words: Acromegaly, Desensitization, Octreotide, MRI

(Endocrine Journal 42: 295-300, 1995)

SOMATOSTATIN analogue (Octreotide) has been used successfully to treat patients with endocrine tumors such as growth hormone $(\mathrm{GH})$-secreting tumor [1], TSH-secreting tumor [2], pancreatic insulinoma [3], and carcinoid tumor [4]. In most cases of acromegaly, the outcome of treatment with octreotide seems favorable in lowering the serum $\mathrm{GH}$ level and often in decreasing tumor size. However, development of the escape phenomenon or desensitization has not been reported [5]. This is the first report of desensitization against octreotide treatment observed in a certain patient with acromegaly. It provides information about the limit of clinical application of long-term octreotide treatment.

Received: August 29, 1994

Accepted: November 25, 1994

Correspondence to: Dr. Toshimasa ONAYA, The Third Department of Internal Medicine, University of Yamanashi Medical School, 1110 Shimokato, Tamaho, Yamanashi 40938, Japan

\section{Case Report}

A 33-year-old female was admitted to our hospital on January 1, 1992 because of amenorrhea. She had her first menses at the age of 14 years and was regular until she was 20 years old. At about the same time she began to notice that her fingers were becoming sausage-shaped and her shoe size was getting larger. At the age of 25 years, an increase in the size of the lower jaw and widening of the nose was noticed by her friends. Amenorrhea and frequent headache started when she was 30 years old. On physical examination, she was 158.5 $\mathrm{cm}$ in height and her body weight was $59.6 \mathrm{~kg}$. Her blood pressure was $136 / 80 \mathrm{mmHg}$ and her pulse rate was $68 / \mathrm{min}$ and regular. She had a typical acromegalic face with a prominent forehead, a big nose, thick lips, macroglossia, soft tissue thickening and acne on her cheeks. Her visual field was not narrowed. Galactorrhea was observed by 
squeezing the breast. Laboratory data revealed a serum GH level of $68.2 \mathrm{ng} / \mathrm{ml}$ and a somatomedin $\mathrm{C}$ level of $785 \mathrm{ng} / \mathrm{ml}$. Her serum free T3, free T4 and prolactine (PRL) were $3.73 \mathrm{pg} / \mathrm{d} l, 1.27 \mathrm{ng} / \mathrm{d} l$ and $5.6 \mathrm{ng} / \mathrm{ml}$, respectively. GH did not respond to $500 \mu \mathrm{g}$ thyrotropin releasing hormone (TRH) stimulation. Leuteinizing hormone (LH) did not respond to $100 \mu \mathrm{g}$ leuteinizing hormone-releasing hormone (LH-RH) stimulation (Table 1). Glucose response was normal after $75 \mathrm{~g}$ OGTT with an oversecretion of insulin. GH secretion was not suppressed. Magnetic resonance imaging (MRI) revealed a pituitary macroadenoma which extended to the suprasellar cisterna to touch the optic chiasm (Fig. 1A, D). Chest X-ray and ECG findings were normal. She was diagnosed as having acromegaly. When bromocriptine (5 mg P.O.) was given, serum GH was not decreased (GH $68.4(0 \mathrm{~h})$ : $70.1(2 \mathrm{~h}): 68.9(4 \mathrm{~h}): 69.7(6 \mathrm{~h}))$. A single injection of $100 \mu \mathrm{g}$ octreotide failed to decrease serum GH (Fig. 2). A higher dose of octreotide $(300 \mu \mathrm{g})$ was also ineffective (GH $77.6(0 \mathrm{~h}): 63.0(3 \mathrm{~h}): 70.4(6$ h)), but in order to decrease the tumor size and to lessen possible damage to the optic nerves during operative procedures, octreotide $100 \mu \mathrm{g}$ tid S.C. and bromocriptine $5 \mathrm{mg}$ tid P.O. were started on February 17 (Fig. 3). Octreotide was gradually in- creased to $200 \mu \mathrm{g}$ tid S.C. on February 27 and 800 $\mu \mathrm{g} /$ day q $6 \mathrm{~h}$ on March 5. This combination therapy produced only a marginal decrease in GH. Somatomedin C was $800 \mathrm{ng} / \mathrm{ml}$ on April 15. MRI examination performed on March 30 revealed a $36 \%$ decrease in tumor size (Fig. 1B, D). Tumor size before and after the treatment was calculated to be $10.24 \mathrm{~cm}^{3}$ and $6.53 \mathrm{~cm}^{3}$, respectively.

Transsphenoidal adenomectomy was performed on April 15, 1992. There was a decrease in basal $\mathrm{GH}$, but a single challenge with bromocriptine (5 $\mathrm{mg}$, P.O.) did not lower the serum GH level (GH $25.6(0 \mathrm{~h}): 27.3(2 \mathrm{~h}): 25.2(4 \mathrm{~h}): 30.4(6 \mathrm{~h}) \mathrm{ng} / \mathrm{ml})$. Bromocriptine, administered ( $2.5 \mathrm{mg}$ bid P.O.) from June 2 to July 3 , was not effective either. The patient was discharged from the hospital on June 22, 1992. A single injection of $100 \mu \mathrm{g}$ octreotide, given on July 13, suppressed $\mathrm{GH}$ at $1 \mathrm{~h}$ after the injection and the suppression continued for $6 \mathrm{~h}$ (Fig. 2). Because of the pain and the inconvenience of multiple injections, the patient refused to have further octreotide injections and she did not agree to take conventional radiation therapy. Bromocriptine was restarted at an increased dose of $5 \mathrm{mg}$ tid P.O. on Aug 3, 1992. Despite continuing treatment with only bromocriptine for about 8 months, the increased serum GH levels were not suppressed (Fig.

Table 1. Endocrinological data

\begin{tabular}{lrrrrrl}
\hline TRH $(500 \mu \mathrm{g})$ & \multicolumn{1}{l}{60} & 90 & 120 & $(\mathrm{~min})$ \\
\hline & 0 & 30 & 60 & & & \\
\hline TSH & 1.2 & 24.2 & 21.3 & 14.9 & 10.1 & $(\mathrm{mU} / \mathrm{ml})$ \\
GH & 65.0 & 69.3 & 66.5 & 70.4 & 66.5 & $(\mathrm{ng} / \mathrm{ml})$ \\
PRL & 5.6 & 13.3 & 8.9 & 7.6 & 6.7 & $(\mathrm{ng} / \mathrm{ml})$ \\
\hline
\end{tabular}

LH-RH $(100 \mu \mathrm{g})$

\begin{tabular}{lrrrrrl}
\hline & 0 & 30 & 60 & 90 & 120 & $(\mathrm{~min})$ \\
\hline LH & $<2$ & 2.2 & $<2$ & $<2$ & $<2$ & $(\mathrm{mIU} / \mathrm{ml})$ \\
FSH & 4.5 & 11.2 & 12.5 & 13.0 & 12.0 & $(\mathrm{mIU} / \mathrm{ml})$ \\
GH & 68.4 & 70.0 & 68.9 & 67.3 & 69.7 & $(\mathrm{ng} / \mathrm{ml})$ \\
\hline
\end{tabular}

$75 \mathrm{~g}$ OGTT

\begin{tabular}{lcccccc}
\hline & 0 & 30 & 60 & 90 & 120 & $(\mathrm{~min})$ \\
\hline BS & 75 & 131 & 143 & 140 & 114 & $(\mathrm{mg} / \mathrm{d} l)$ \\
IRI & 34 & 111 & 188 & 208 & 156 & $(\mu \mathrm{U} / \mathrm{m} l)$ \\
GH & 68.5 & - & 67.7 & - & 66.1 & $(\mathrm{ng} / \mathrm{m} l)$ \\
\hline
\end{tabular}

OGTT, oral glucose tolerance test; BS, blood sugar; IRI, immunoreactive insulin. 


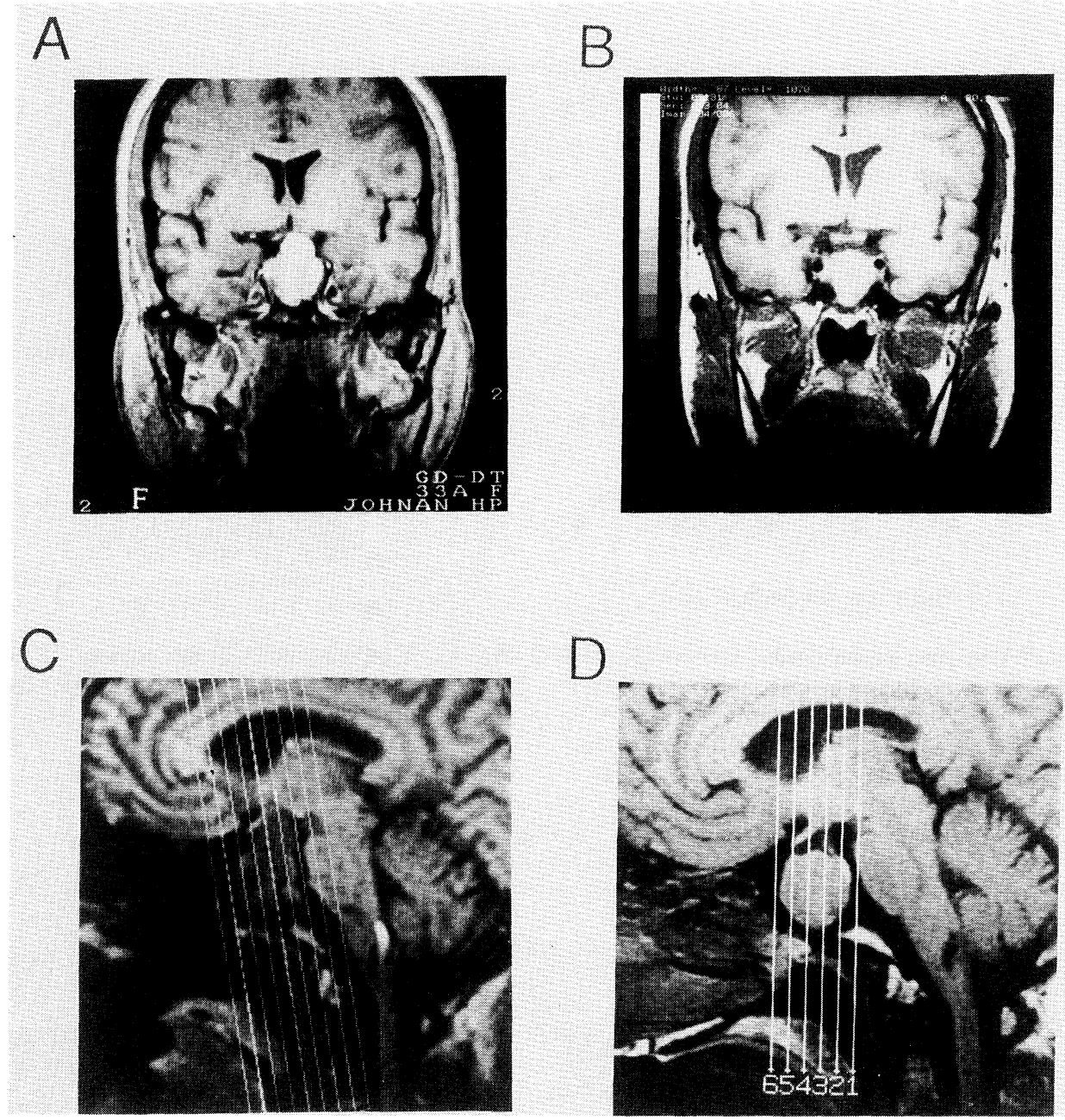

Fig. 1. Coronal and saggital MRI scan before and after octreotide treatment before surgery. A coronal section, C saggital section: A mass that was enhanced with GaTd was detected in and above the sella turcica. The examination was carried out on January 24, 1992. B coronal section, D saggital section: The mass decreased in size and oppression of the optic chiasm was resolved. The examination was carried out on March 30, 1992.

3). Plasma GH reached $48.2 \mathrm{ng} / \mathrm{ml}$ and somatomedin C reached $926 \mathrm{ng} / \mathrm{ml}$ on January 18, 1993. Higher doses of bromocriptine than $15 \mathrm{mg} /$ day were unendurable because of gastric side effects. An MRI examination performed on March 9, 1993 revealed residual pituitary adenoma tissue below the fat tissue that was planted during the operation (Fig. 4A). She agreed to resume taking octreotide. In addition to bromocriptine, octreotide was restarted at a dosage of $100 \mu \mathrm{g}$ bid S.C. on March 10, 1993. Plasma GH examined at every visit decreased to near the normal range. On May 19, 1993 her GH level reached its lowest point ever
(7.9 ng/ml). Her serum PRL was $0.06 \mathrm{ng} / \mathrm{ml}$. GH was kept relatively low for about 6 months, until September. Somatomedin C was 366, 392 and 267 $\mathrm{ng} / \mathrm{ml}$ on July 1 , July 14 and July 28 , respectively. On August 25, plasma somatomedin $\mathrm{C}$ was the lowest it had ever been $(254 \mathrm{ng} / \mathrm{ml})$, indicating that octreotide was effective. The patient noticed a substantial decrease in headache. Her menses and ovulation resumed.

After September, her GH and somatomedin C gradually increased to levels as high as those seen before octreotide injection. On December 15, GH and somatomedin C was $52.8 \mathrm{ng} / \mathrm{ml}$ and $883 \mathrm{ng} /$ 


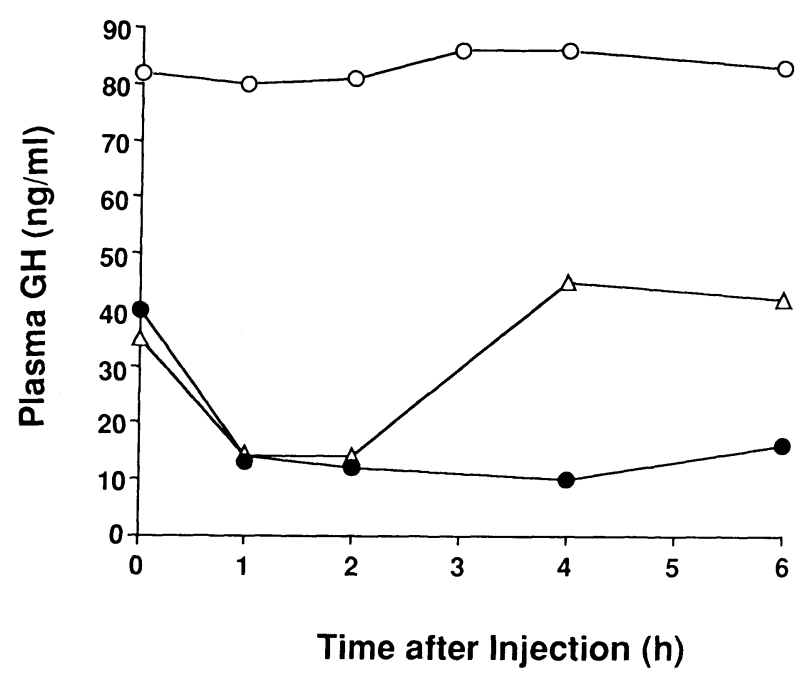

Fig. 2. Plasma GH response to octreotide. Octreotide (100 $\mu \mathrm{g}, \mathrm{sc})$ was injected into the patient before transsphenoidal surgery (-O-: February 14, 1992), after surgery (-O-: July 13, 1992) and after longterm octreotide treatment $(-\triangle-$ : February 9,1994$)$.

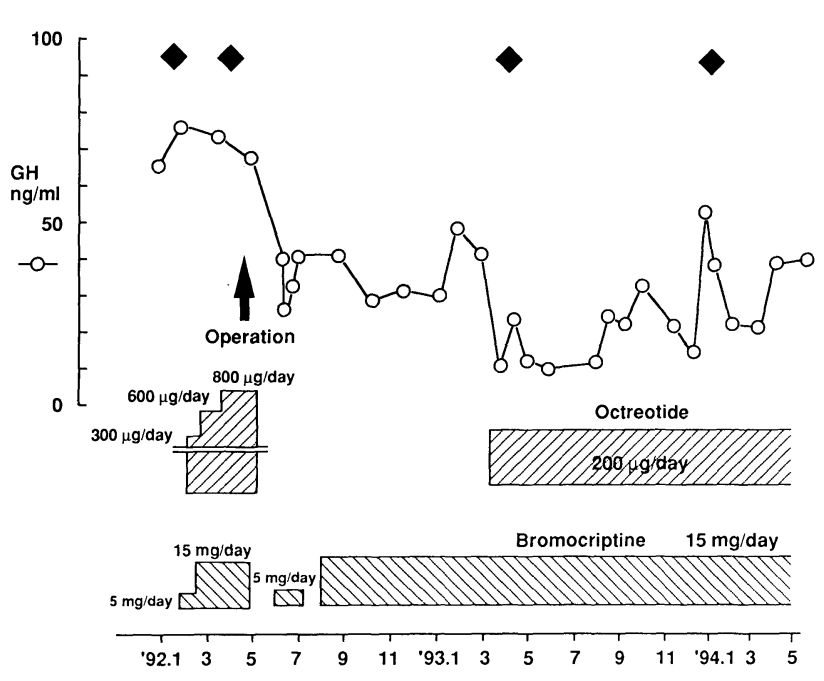

Fig. 3. Clinical course of the patient. The serum level of $\mathrm{GH}(\mathrm{ng} / \mathrm{ml})$ is shown $\left(-\bigcirc_{-}\right)$. MRI studies are indicated by the symbol $(\diamond)$ and their results are shown in Figs. 1 and 4.

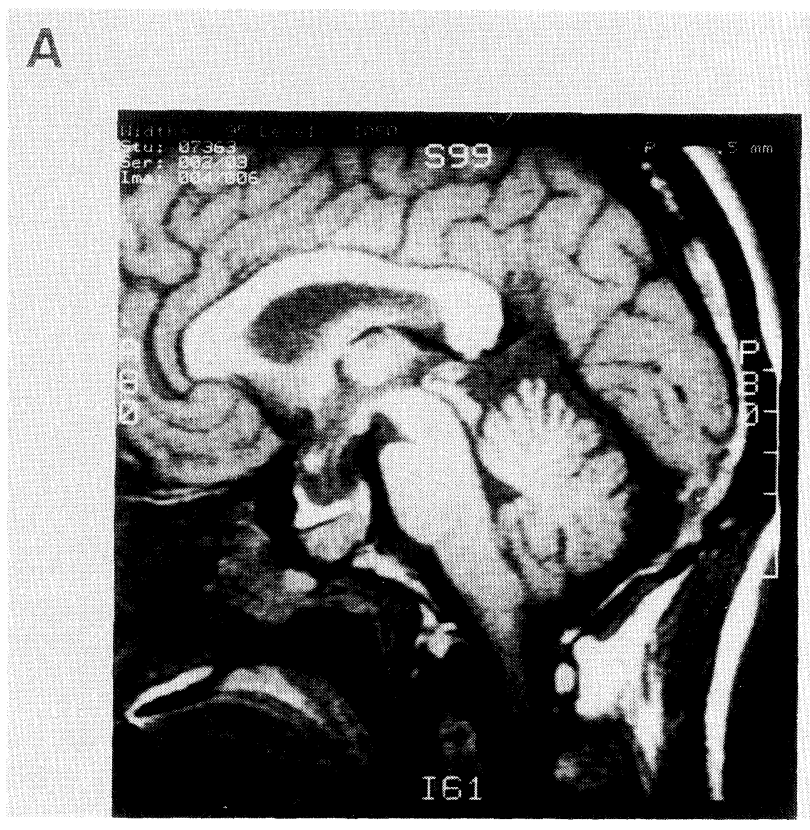

B

Fig. 4. Saggital MRI scan before and after long-term octreotide treatment after transsphenoidal surgery. Under the fat tissue (a high signal intensity area), residual adenoma tissue was observed in MRI taken before (A: March 9, 1993) and after (B: December 13, 1993) the long-term octreotide treatment. 
$\mathrm{ml}$, respectively. This escape or desensitization phenomenon could have been caused by either 1) an increase in the size of the residual pituitary tumor rendering the dose of octreotide relatively small or 2) a decrease in responsiveness of the residual pituitary tumor. To exclude the first possibility, MRI was performed on December 13, 1993. As shown in Fig. 4B, the tumor appeared to be smaller than before starting the daily octreotide injections. To explore the second possibility, a single injection of octreotide $100 \mu \mathrm{g}$ was administered. $\mathrm{GH}$ decreased $1 \mathrm{~h}$ and $2 \mathrm{~h}$ after the injection, but the suppression was not maintained at $4 \mathrm{~h}$ and $6 \mathrm{~h}$ (Fig. 2). During the course of octreotide therapy, the patient did not develop diarrhea or cholelithiasis and her serum thyroid hormone level remained normal. Because of the remaining pituitary tumor and the occurrence of desensitization of octreotidedependent suppression of GH secretion, the patient will be treated with $\gamma$-knife radiation. The following advantages of the $\gamma$-knife treatment which cannot be obtained with conventional radiation therapy helped us to choose the $\gamma$-knife treatment. First, the procedure can be completed within one day. Second, a higher dose of radiation can be applied to a small target such as a residual tumor.

GH and somatomedin C were measured by RIA obtained from Daiichi Radioisotope Laboratory (Tokyo, Japan) and Chiba Corning Diagnostics (Tokyo, Japan), respectively. The normal range for somatomedin $\mathrm{C}$ provided by the manufacturer is from 127 to $403 \mathrm{ng} / \mathrm{ml}$.

\section{Discussion}

Somatostatin is a peptide that is known to suppress secretion of various hormones[6] and to regulate the growth of endocrine cells. Since somatostatin has a very short half-life, its clinical use is limited. On the other hand, octreotide is a synthetic somatostatin analogue that has a longer half-life; it had been used to treat patients with acromegaly [1] or pancreatic tumors with a low percentage of minimal side effects [3. 7]. It has been reported that 100 to $600 \mu \mathrm{g}$ of octreotide per day is sufficient to decrease $\mathrm{GH}$ and sometimes to decrease the tumor size. In our patient, GH decreased by only $12 \%$, from 77 to $68 \mathrm{ng} / \mathrm{ml}$, when octreotide $300 \mu \mathrm{g} /$ day in combination with bromocriptine was given before the operation, while the size of the tumor decreased by $36 \%$. A part of the tumor, especially, which extended above the sella and decreased in size in response to octreotide, might have been inactive in producing GH. It is interesting to speculate that such functional heterogeneity within the tumor $[8,9]$ may exist.

When octreotide was resumed 1 year after the operation, a single injection of $200 \mu \mathrm{g}$ was sufficient to decrease plasma GH. This was probably made possible by the partial removal of the tumor tissue by adenomectomy as reported by Weeke $e t$ al. [10]. Since octreotide was administered with bromocriptine, it is difficult to evaluate the single effects of octreotide. However, bromocriptine was not effective when a single dose of $5 \mathrm{mg}$ was administered, and when the patient had been treated with bromocriptine for 8 months, it did not suppress plasma $\mathrm{GH}$ even to the level which was observed after the adenomectomy. Suppression of somatomedin $\mathrm{C}$ was not observed either. We therefore believe that octreotide rather than bromocriptine caused the transient decrease in serum $\mathrm{GH}$ and somatomedin $\mathrm{C}$ from March to August, 1993 followed by desensitization. This desensitization was not caused by the increase in tumor size as evidenced by MRI. It is possible that during long-term octreotide treatment, clonal selection of octreotide-unresponsive cells occurred. It is also possible that the balance between the alternatively spliced isoform of somatostatin receptors might have changed [11].

Desensitization is a ubiquitous phenomenon observed in many cells and tissues. Prior exposure to somatostatin is known to cause attenuation of somatostatin-dependent inhibition of GH response to GHRH stimulation in man [12]. As for octreotide, desensitization has also been reported in vitro [13]. The mechanism of this phenomenon is believed to be caused by decreasing the number of receptor on the cell surface. Since somatostatin and octreotide should use the same receptors [14], it would not be surprising if octreotide-dependent desensitization happened in vivo, but desensitization has been reported in only a few patients with gastrointestinal tumors [15] but not in those with pituitary GH secreting tumors.

In our daily practice of endocrine medicine, the treatment of patients who have high GH levels after initial pituitary surgery is sometimes difficult. Treatment with bromocriptine and/or octreotide is usually recommended [16, 17]. For those who 
do not respond to treatment with bromocriptine and/or octreotide, we suggest having a second operation or conventional radiation therapy, but not all the patients agree. $\gamma$-Knife treatment is also a good choice [18], but the expense of this treatment hinders many patients.

In the present case, although we could not achieve complete suppression of $\mathrm{GH}$, we could obtain somewhat satisfactory suppression of GH with a relatively low dose of octreotide, but this effect did not last for more than 6 months.

Our findings call for attention to the limits to long-term octreotide treatment in patients with acromegaly.

\section{References}

1. Vance ML, Harris AG (1991) Long-term treatment of 189 acromegalic patients with the somatostatin analog octreotide. Result of the International Multicenter Acromegaly Study Group. Arch Intern Med 151:1573-1578.

2. Peccoz BP, Mariotti S, Guillausseau PJ, Medri G, Piscitelli G, Bertoli A, Barbarino A, Rondena M, Chanson P, Pinchera A (1987) Treatment of hyperthyroidism due to inappropriate secretion of thyrotropin with the somatostatin analog SMS 201995. J Clin Endocrinol Metab 68: 208-214.

3. Maton PN (1993) Use of octreotide acetate for control of symptoms in patients with islet cell tumors. World J Surg 17: 504-510.

4. Arnold R, Neuhaus C, Benning R, Schwerk WB, Trautmann ME, Joseph K, Bruns C (1993) Somatostatin analog sandostatin and inhibition of tumor growth in patients with metastatic endocrine gastroenteropancreatic tumors. World J Surg 17: 511519.

5. Tolis G (1988) Long-term management of acromegaly with somatostatin. Hormone Research 29: 112-114.

6. Reichlins S (1992) Neuroendocrinology: Growth hormone regulating factors. In: Wilson JD, Foster DW (eds) Textbook of Endocrinology. W.B. Saunders Company: 159-162.

7. Lamberts SWJ (1986) Non-pituitary actions of somatostatin: a review on the therapeutic role of SM 201-995 (Sandostatin). Acta Endocrinol 276 (Suppl): 41-55.

8. Hofland LJ, van-Koetsveld PM, Lamberts SW (1990) Percoll density gradient centrifugation of rat pituitary tumor cells: a study of functional heterogeneity within and between tumors with respect to growth rates, prolactin production and responsiveness to the somatostatin analog SMS 201-995. Eur J Cancer 26: $37-44$.

9. Bando H, Sano T, Ohshima T, Zhang CY, Yamasaki R, Matsumoto K, Saito S (1993) Difference in pathological findings and growth hormone responses in patients with growth hormone-producing pituitary adenoma. Endocrinol Japon 39: 355-363.

10. Weeke J, Orskov H, Christensen SE, Kaal A, Skjaerbaek C, Illum P, Jorgensen J, Lunde E, Haubek A, Poulsen JH (1993) Long-term treatment with octreotide of patients with acromegaly. Ugeskrift for Laeger 155: 2592-2598.

11. Vanetti M, Vogt G, Hollt V (1993) The two isoforms of the mouse somatostatin receptor (mSSTR2A and mSSTR2B) differ in coupling efficiency to adenylate cyclase and in agonist-induced receptor desensitization. FEBS-Lett 331: 260-266.

12. Kelijman M, Frohman LA (1990) Impaired inhibitory effects of somatostatin on growth hormone (GH)-releasing hormone stimulation of GH secretion after short term infusion. J Clin Endocrinol Metab 71: 157-163.

13. Koper JW, Hofland LJ, van-Koetsveld PM, denHolder F, Lamberts SW (1990) Desensitization and resensitization of rat pituitary tumor cells in longterm culture to the effects of the somatostatin analogue SMS 201-995 on cell growth and prolactin secretion. Cancer Res 50: 6238-6242.

14. Kvols LK, Reubi JC, Horisberge U, Moertel CG, Rubin J, Charboneau JW (1992) The presence of somatostatin receptors in malignant neuroendocrine tumor tissue predicts responsiveness to octreotide. Yale J Biol Med 65: 505-518.

15. Koelz A, Kraenzlin M, Gyr K, Meier V, Bloom SR, Heitz P, Stalder H (1987) Escape of the response to a long-acting somatostatin analogue (SMS 201-995) in patients with VIPoma. Gastroenterology 92: 527531.

16. Weiss MH (1993) Acromegaly. In: Rakel R (ed) Conn's Current Therapy. W.B. Saunders Company: 597-600.

17. Melmed S (1993) Acromegaly. In: Mazzaferri EL, Samaan NA (eds) Endocrine Tumors. Blackwell Scientific Publications: 113-123.

18. Terahara A (1993) Gamma Knife. Gan to Kagaku Ryoho 20: 2133-2142 (In Japanese). 